\title{
EFFECT OF STORAGE TEMPERATURE ON THE PHYSICOCHEMICAL PROPERTIES OF BROMUCONAZOLE FUNGICIDE FORMULATION AND ON RESIDUES IN CUCUMBER FRUITS
}

\author{
(Received:10.1.2011) \\ By \\ O.A. Radwan
Pesticides Analysis Department, Central Agricultural Pesticides Laboratory,Agriculture Research Center, Doki, Giza, Egypt

\begin{abstract}
Bromuconazole fungicide formulation recommended to be used for pest control in Egypt was subjected to storage conditions at $54{ }^{\circ} \mathrm{C}$ for 3 and 14 days and at $72{ }^{\circ} \mathrm{C}$ for 3 days. The effect of storage temperature on the chemical stability and the physical properties of Vectra (bromuconazole) was recorded. An IR analysis showed that the percentage match of bromuconazole formulation was more than $96 \%$ at different storage conditions. On the other hand, the results showed that the physical properties (Emulsification test) were not affected by all storage conditions. Cucumber plants were treated with the recommended rate of bromuconazole under the normal field conditions in the summer season of 2009 . The residue analysis showed that the initial deposits were $0.5995 \mathrm{ppm}$ and $0.8627 \mathrm{ppm}$ for bromuconazole L- 5850646 and bromuconazole L-5850647, respectively in cucumber fruits .The percentage of loss was 53.59 and $81.92 \%$ for bromuconazole L- 5850646 and bromuconazole L-5850647 , respectively in cucumber fruits determined one day after treatment .The residual half life period in washed and unwashed cucumber fruits was $22.39 \& 14.65$ hours for 1,2 bromuconazole formulation respectively. Washing process was an effective method for value $0.2103 \mathrm{ppm}$ for bromuconazole L5850646 while, bromuconazole L-5850647 was not detected as initial deposit residue on cucumber fruits. The pesticide residues were dissipated to different degrees, with the time elapsed after spraying .
\end{abstract}

Key words:bromuconazole, physical properties, residue analysis.

\section{INTRODUCTION}

Bromuconazole systemic fungicide from triazole pesticides group, is used against Ascomycetes, Basidiomycetes and Fungi including Alternaria, Fusarium, black and yellow Sigatoka, and Pseudocercosporella spp. in cereals, fruit, vines, vegetables, tropical crops, turf and ornamentals. Pesticides may fail to comply with the FAO/WHO meeting specifications 2002 required if it is improperly stored. Chemical and physical instability usually lead to the deterioration of the active ingredient $(a, i$. ) content and emulsion stability under the variable climatic conditions ( Emara \& Atalla 2006 ; Emara \&Abdel Aziz 2007 , Radwan \& Atalla 2009 ; Sandro et al., 2010). The Ministry of Agriculture in Egypt follows FAO and WHO specification. The objective of the present work was aimed to determine and evaluate the physical and chemical properties of Vectra 10\% EC( bromuconazole).In addition, the purpose of this study was to demonstrate the determination of bromuconazole in Cucumber fruits. This will reveal the rate of its persistence in the plants to determine the Pre Harvest Interval (PHI) that should pass after the last treatment and before harvesting for normal human consumption. Washing process to remove surface residues and consequently shortening the safe intervals perior to harvesting was evaluated (Nasr 2002: Hala 2003; Osman et al..2004: Emara \&Atalla 2006 ; and Radwan \& Atalla 2009).

\section{MATERIALS AND METHODS}

\subsection{Fungicide used}

Vectra $(\mathbf{1 0 \%}$ SC.) :fungicide from (Bayer CropSience).

Chemical name: 1-[[4-bromo-2-(2,4-

dichlorophenyl)tetrahydro-2-furanyl]methyl]- $1 \mathrm{H}$ 1,2,4-triazole. Fig. (1).

\subsection{Chemical analysis}

\subsubsection{Active ingredient percentage}

Active ingredient percentage was determined before and after storage for tested fungicide Vectra by HPLC instrument according to Gfont $e t$ 
al.,(1999); Pesticides Analytical Manual (2004) ; and Lidia et al.,( 2006).

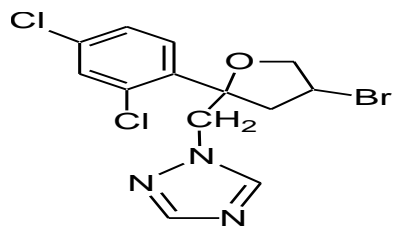

Fig.(1): The chemical structure of bromuconazole. HPLC conditions

High performance liquid chromatography instrument (Agillent serial 1100)solvent delivery system and quaternary pump with a C18 stainless steel column $(2.4 \mathrm{X} 250 \mathrm{~mm})$ and UV detector was used under the following conditions as shown in Table (1) and Figure (2).

Preparation of standard solution

Weigh $10 \mathrm{mg}$ (related to a purity of $100 \%$ ) from both bromuconazole L- 5850646 and L5850647 reference standard of fungicide into a 10 $\mathrm{ml}$ volumetric flask and dilute to the mark with acetonitrile LC grade and mixing well .This is the standard solution.

\section{Calibration}

Duplicate injections $(2 \mu \mathrm{l})$ of calibration solution and each sample were injected and integrated areas for each peak was recorded . Bromuconazole $10 \%$ is a mixture of two diasteroisomers in proportion(L-5820646 5\% \& L-5850647 5\%) content in each sample was calculated compared with an external standard.

2.3. Absorbance of Vectra formulation in infrared (IR spectra) .

The Fourier transform infrared (Avtar 330 Thermo Nicolet) was used to study the effect of storage on the absorbance of function groups and finger print of bromuconazole according to the method of Barbra (1985) with some modification. Samples were prepared by homogenizing $0.01 \mathrm{~g}$ of sample with $0.1 \mathrm{~g}$ of dry $(\mathrm{KBr})$ by agatemortar and pests to a clean stainless steel slide and placed in piston to make a clear and thin film of desk sample.

\subsection{Proton magnetic resonance (HNMR) of bromuconazole.}

The (HNMR) spectra of the fungicide bromuconazole under present investigation have been recorded inDi Methyl Sulfoxide (DMSO)as a solvent and tetra methyl silane (TMS) as an internal reference with $90 \mathrm{MHz}$ signal and 4.000 gauss magnetic field.

2.5.Separation and fragmentation of bromuconazole fungicide formulation by GC equipped with a mass spectrometric detector (GC/MS spectra)
The GC/MS analysis was used to compare the separation and fragmentation of pesticide formulations before and after storage according to the method of Saad et al., (1993).GC/MS analysis was performed with an Agilent 6890 gas chromatograph equipped with a mass spectrometric detector (MSD) model Agilent 5973. A fused silica capillary column (HP-5MS), $5 \%$ phenyl polysiloxane as non polar stationary phase $(30 \mathrm{~m} \times 0.25 \mathrm{~mm}$ i.d)and $0.25 \mu \mathrm{m}$ film thickness.

\section{Operating condition was as follows}

Injector port temperature, $210^{\circ} \mathrm{C}$. The helium was used as a carrier gas at a flow rate of $1 \mathrm{ml} / \mathrm{min}$. Pulsed splitless mode. The column temperature was maintained at $80{ }^{\circ} \mathrm{C}$, for $3 \mathrm{~min}$. Then, programmed at $10{ }^{\circ} \mathrm{C} / \mathrm{min}$ to $240{ }^{\circ} \mathrm{C}$, and held for $20 \mathrm{~min}$. The total analysis time was $30 \mathrm{~min}$. A $(1 \mu 1)$ volume was injected splitless. The mass spectrometric detector (MSD) was operated in electron impact ionization mode, scanning from $\mathrm{m} / \mathrm{z} 50$ to 550 . The ion source temperature was $230{ }^{\circ} \mathrm{C}$ and the quadrupole temperature $150{ }^{\circ} \mathrm{C}$. The electron multiplier voltages (EM voltage) was maintained $1100 \mathrm{~V}$ above autotun, and solvent delay of 3 min was employed. The instrument was manually turned using heptacosa fluoro tributyl amine (HFTBA).

\section{6 .Thermal stabilityof bromuconazole under storage conditions}

Samples of bromuconazole formulation were stored in glass package, in the oven at $54^{\circ} \mathrm{C} \pm 2^{\circ} \mathrm{C}$ for $3 \& 14$ days and at $72{ }^{\circ} \mathrm{C}$ for 3 days .

\subsubsection{Emulsion stability test}

Five $\mathrm{ml}$ of Vectra samples before and after storage were added to a graduated $100 \mathrm{ml}$ cylinder filled with $95 \mathrm{ml}$ hard water (prepared according to CIPAC MT36) by means of pipette, and then the samples were pour onto the water directed to the center. Stopper the cylinder and invert it for 30 times, and then placed in a water bath maintained at $30{ }^{\circ} \mathrm{C} \pm 1$ for $30 \mathrm{~min}$. If there is any forming of oily or creamy layer either at the top or the bottom of the cylinders must not be exceed than $2 \mathrm{ml}$ according to WHO( 1979and 1985).

\subsection{Persistence of bromuconazole under field} conditions

\subsubsection{Field experimental and sampling}

Cucumber plants were planted at a selected farm at Kafr Shokr, Kalyobia Governorate on May 2009 in plots of 1/100 feddan each. The plots received the normal agronomic practices throughout the experimental period. Vectra (10\%) was sprayed on May $10^{\text {th }} 2009$ at the recommended rate $100 \mathrm{Cm}^{3} . / 100 \mathrm{~L}$. water / 
feddan. A knapsack sprayer equipped with one nozzle was used .Besides another plots were left untreated as a control in both treatments. Representative samples of mature cucumber fruits(four replicates) were taken at random one hour after application. Subsequent samples were taken 1,3,5,7,and 14 days after treatment. Each sample was divided into two subsamples, the first was washed with tap water for $1 \mathrm{~min}$ and the second was left unwashed, the subsamples were stored in poly ethylene bags until analysis.

\subsubsection{Extraction and clean up of bromuconazole fungicide}

Levels of bromuconazole in cucumber fruits were determined according to the method of Nasr (2002) with some modification. Pesticide residues were extracted with $100 \mathrm{ml}$ acetone using the warning blender partitioned into n-hexane. The extract was carefully decanted and filtered through filter paper Watman no.1 then dried through anhydrous sodium sulphate and evaporated on water bath at $40{ }^{\circ} \mathrm{C}$ to dryness by using rotary evaporator. The resulting extract of cucumber fruits was cleared by $\mathrm{C} 18$ cartridge column chromatography. The fungicide extracts were evaporated at $30{ }^{\circ} \mathrm{C}$ to dryness, residues were dissolved in $1 \mathrm{ml}$ acetonitrile and then determined by Agilent HPLC apparatus at the same conditions as described above. Obtained results were corrected according to the rate of recovery, which were determined in fortified untreated samples. Following the techniques previously mentioned, the recovery rate of bromuconazole L-5850646 \& bromuconazole L-5850647 was 97.99 \& $96.09 \%$, respectively. Student's (t) test was used to analyze the statistical significance between the same treatments (Gad and Weil, 1989).

\section{RESULTS AND DISCUSSION \\ 3.1.Effect of storage temperature on chemical properties}

\subsubsection{Active ingredient percentage}

The data in Table (2) show that thermal stability of the active ingredient $\%$ of bromuconazole fungicide was not affected by storage condition periods. The data indicate that bromuconazole L- 5850646 stored at $54{ }^{\circ} \mathrm{C}$ for 3 $\& 14$ days and at $72{ }^{\circ} \mathrm{C}$ for 3days were $4.93,4.89$ , and $4.71 \%$ and for bromuconazole L- 5850647 were $4.86,4.77$ and $4.63 \%$ stored at $54{ }^{\circ} \mathrm{C}$ for 3 \& 14 days and at $72{ }^{\circ} \mathrm{C}$ for 3days,stored respectively. The bromuconazole a.i $\%$ in all storage conditions were within permissible limits for Pesticides Specification (2006) which was declared content $\mathrm{g} / \mathrm{L}$. Above 25 up to 100 the tolerance was $\pm 10 \%$ or the percentage of bromuconazole active ingredient content $\left({ }^{\circ} \pm\right.$ $1 \%$ ), whereas the bromuconazole active ingredient percentage was represented by $9.85 \%$ of the zero time sample. The degradation of active ingredient content in pesticideformulations under storage temperature conditions was noticed by Emara 2006 ; Emara \&Atalla 2006 ; Radwan \& Atalla 2009 and Radwan 2010.

\subsubsection{Effect of storage temperatures on physical properties (Emulsion test)}

The formulation of bromuconazole fungicide passed successfully through emulsion test in different types of storage and comply with WHO specifications (1979)except in storage at $72{ }^{\circ} \mathrm{C}$ for 3 days. The cream layer $(0.5 \mathrm{ml})$ appeared but it was within permissible limits $(2 \mathrm{ml})$.

\subsubsection{The effect of storage temperature on the absorbance of bromuconazole} formulation in infrared

The data obtained from the IR spectra of bromuconazole $10 \% \mathrm{EC}$ samples initial, room temperature $\left(54{ }^{\circ} \mathrm{C}\right.$ for $3 \& 14$ days and at $72{ }^{\circ} \mathrm{C}$ for 3days of application) showed no significant changes in IR spectra during the different types of storage e.g., at $54^{\circ} \mathrm{C}$ for $3 \& 14$ days. All the IR spectra of the bromuconazole samples showed the same bands but with different intensity due to the degree of the degradation of the active ingredient during the hot storage $54^{\circ} \mathrm{C}$ for $3 \& 14$ days. The samples showed the characteristic bands of bromuconazole as follows:

1- The bonds of halide substituted benzene ring C$\mathrm{X}$ appeared peaks at $790-820 \mathrm{~cm}^{-1}$.

2 - The C-H bonds aliphatic and aromatic appeared their peaks at $2843 \pm 10 \mathrm{~cm}^{-1}$ and $2927 \pm 10 \mathrm{~cm}^{-1}$, respectively.

3- The (N) Nitrogen atom in cyclic amid appeared its peaks at $1637 \mathrm{~cm}^{-1}$.

4- The (O) Oxygen atom in ethoxylated ester appeared their peaks at 1105.64.

The IR spectrum analysis of bromuconazole fungicide characterized by the presence of peaks between $2871 \mathrm{~cm}-1$ and $2929 \mathrm{~cm}-1$ supported the presence of methyl group (-CH3, $-\mathrm{CH} 2$ and $\mathrm{CH}$ ), also O-C-O group was characterized by IR between 1105 and $1154 \mathrm{~cm}-1$.The infrared spectrum of bromuconazole analysis and the effect of different type of storage on the absorbance are presented in Table (3). Characterizing the structure of bromuconazole appeared as bands of nitrogen $(\mathrm{N})$ atom at $3442.01 \mathrm{~cm}-1$ and disappeared after storage at $54^{\circ} \mathrm{C}$ for 14 days and $72^{\circ} \mathrm{C}$ for 3 
Table (1): Bromuconazole calibration parameters.

\begin{tabular}{|c|c|c|c|c|c|c|c|c|c|c|c|}
\hline $\begin{array}{l}\text { Solvent } \\
\text { system }\end{array}$ & $\begin{array}{l}\text { Flow } \\
\text { rate } \\
\mathrm{ml} / \mathrm{min}\end{array}$ & $\begin{array}{c}\text { Retentio } \\
\text { n time } \\
(\mathrm{min})\end{array}$ & $\begin{array}{l}\text { Regression } \\
\text { coefficient } \\
\text { (R2) }\end{array}$ & $\begin{array}{c}\text { Standard } \\
\text { deviation } \\
\text { SD }\end{array}$ & $\begin{array}{c}\text { Relatively } \\
\text { SD }\end{array}$ & \multicolumn{2}{|c|}{ Slope } & \multicolumn{2}{|c|}{$\begin{array}{l}\text { Limit of } \\
\text { detection } \\
\text { LOD(ng) }\end{array}$} & \multicolumn{2}{|c|}{$\begin{array}{c}\text { Limit of } \\
\text { quantization } \\
\text { LOQ(ng) }\end{array}$} \\
\hline $\begin{array}{c}\text { Acetonitrile } \\
90 \% / \text { methano } \\
110 \%\end{array}$ & 1 & $\begin{array}{l}\text { (1) } 3.854 \\
\text { (2) } 4.020\end{array}$ & $\begin{array}{l}0.9998 \\
0.9898\end{array}$ & $\begin{array}{l}6.519 \\
5.981\end{array}$ & $\begin{array}{l}0.0010 \\
0.0011\end{array}$ & 1.66 & 1.59 & 1.243 & 1.438 & 8.1 & 8.6 \\
\hline
\end{tabular}

Table (2): Active ingredient \% in bromuconazole at different storage temperatures and periods.

\begin{tabular}{|c|c|c|c|c|c|}
\hline \multirow{2}{*}{$\begin{array}{c}\text { Type of } \\
\text { storage }\end{array}$} & $\begin{array}{c}\text { Storage } \\
\text { period } \\
\text { (day) }\end{array}$ & \multicolumn{2}{|c|}{ Active ingredient\% } & \multicolumn{2}{c|}{ Loss \% } \\
\cline { 3 - 6 } & & $(\mathbf{1})$ & 4.87 & $\ldots \ldots$ & $\ldots \ldots$ \\
\hline $\begin{array}{c}\text { Room } \\
\text { temperature }\end{array}$ & Initial & 4.98 & 4.86 & 1.004 & 0.2053 \\
\hline $\mathbf{5 4}^{\mathbf{0}} \mathbf{C}$ & 3 day & 4.93 & & & \\
\hline
\end{tabular}

Initial = One hour before storage. Each value is a mean of three replicates of samples.

1= Bromuconazole L- 5850646 (5\%) $\quad$ 10\% Bromuconazole - 2= Bromuconazole L- 5850647 (5\%)

Table (3 ) : Storage temperatures on finger print of formulated bromuconazole by using IR spectrum.

Position of bands Cm-1

\begin{tabular}{|l|l|l|l|}
\hline Bromuconazole & $\left.\mathbf{( 5 4}^{\circ} \mathbf{C}\right)$ for 3 days & $\mathbf{5 4}{ }^{\circ} \mathbf{C}$ for $\mathbf{1 4}$ days & $\mathbf{7 2}^{\circ} \mathbf{C}$ for $\mathbf{3}$ days \\
\hline 468.03 & 466.13 & 468.19 & 469.36 \\
\hline 540.69 & 541.66 & 541.01 & 537.53 \\
\hline 722.08 & 722.07 & 722.11 & 754.83 \\
\hline 935.53 & 933.59 & 941.11 & 912.72 \\
\hline 1035.85 & 1035.05 & 1031.55 & 1031.90 \\
\hline 1154.04 & 1154.64 & 1156.61 & $(\mathrm{I})$ \\
\hline 1304.40 & 1303.43 & 1301.88 & $(\mathrm{I})$ \\
\hline 1376.63 & 1376.63 & 1376.63 & 1380.57 \\
\hline 1456.65 & 1456.65 & 1456.61 & 1468.47 \\
\hline 1658.47 & 1658.47 & 1657.43 & 1637.44 \\
\hline 2286.18 & 2286.18 & $(\mathrm{I})$ & $(\mathrm{I})$ \\
\hline 2724.13 & 2724.98 & $(\mathrm{I})$ & $(\mathrm{I})$ \\
\hline 2843.29 & 2841.31 & 2841.66 & $(\mathrm{I})$ \\
\hline 3442.01 & 3442.00 & $(\mathrm{I})$ & $(\mathrm{I})$ \\
\hline Match $\%$ & 100 & 98.86 & 96.13 \\
\hline
\end{tabular}

(I) = Disappear band.

Table (4): Separation and fragmentation of bromuconazole insecticide formulation.

\begin{tabular}{|c|c|c|c|c|}
\hline Type of storage & RT & Expected compound name & Formula & MW \\
\hline $\begin{array}{l}\text { Bromuconazole } \\
\text { (Initial)at one hour } \\
\text { Before and after } 3 \\
\text { \&14 days of storage } \\
\text { at } 54^{\circ} \mathrm{C}\end{array}$ & $\begin{array}{l}22.96 \\
25.50 \\
26.06\end{array}$ & $\begin{array}{l}\text { Benzoic acid ,2,4 dichloro- (4-methoxyphenyl) } \\
\text { Benzamide, 2,4 dichloro - } \mathrm{N}-(2,5 \\
\text { dimethylphenyl) } \\
\text { 1-[[4-bromo-2-(2,4-dichlorophenyl)tetrahydro-2- } \\
\text { furanyl]methyl]-1H-1,2,4-triazole }\end{array}$ & $\begin{array}{l}\text { C11H16Cl2NO2 } \\
\text { C14H12Cl2O2 } \\
\text { C13H12N3OCl2Br }\end{array}$ & $\begin{array}{l}218.00 \\
308.31 \\
374.95\end{array}$ \\
\hline $\begin{array}{l}\text { After } 3 \text { days of } \\
\text { storage at } 72^{\circ} \mathrm{C}\end{array}$ & $\begin{array}{l}9.99 \\
24.49 \\
25.83\end{array}$ & $\begin{array}{l}\text { 2,3,5,6-Tetrachloropyridine } \\
\text { 2-Amino-6-bromo-4-methoxyphenol } \\
\text { 2,2- Dichloro-1-(2,4- dichloro-phenyl) }\end{array}$ & $\begin{array}{l}\text { C5HCl4N } \\
\text { C7H8BrNO2 } \\
\text { C10H5Cl4N30 }\end{array}$ & $\begin{array}{l}215.00 \\
218.05 \\
323.00\end{array}$ \\
\hline $54^{\circ} \mathrm{C}$ (3day) & \multicolumn{4}{|c|}{ Like completely } \\
\hline $54^{\circ} \mathrm{C}$ (14day) & \multicolumn{4}{|c|}{ Like completely } \\
\hline $7^{\circ} \mathrm{C}$ (3day) & \multicolumn{4}{|c|}{ Like completely } \\
\hline
\end{tabular}




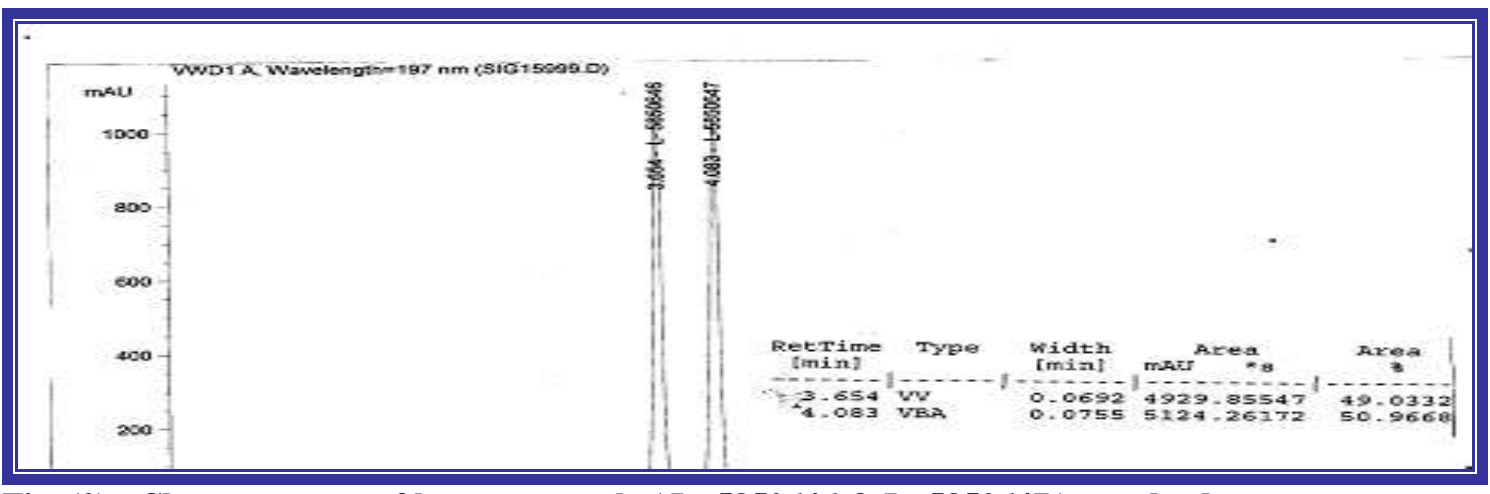

Fig. (2) : Chromatogram of bromuconazole ( L- 5850646 \& L- 5850647 ) standard

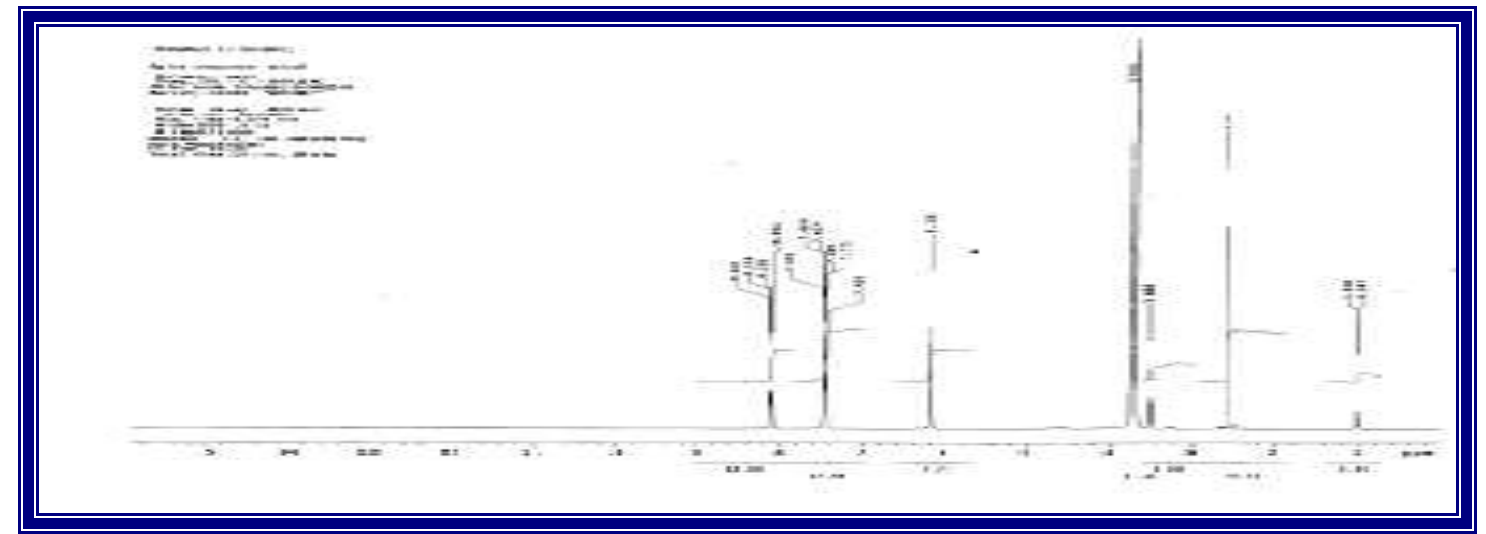

Fig.(3) : Proton NMR spectrum for bromuconazole fungicide

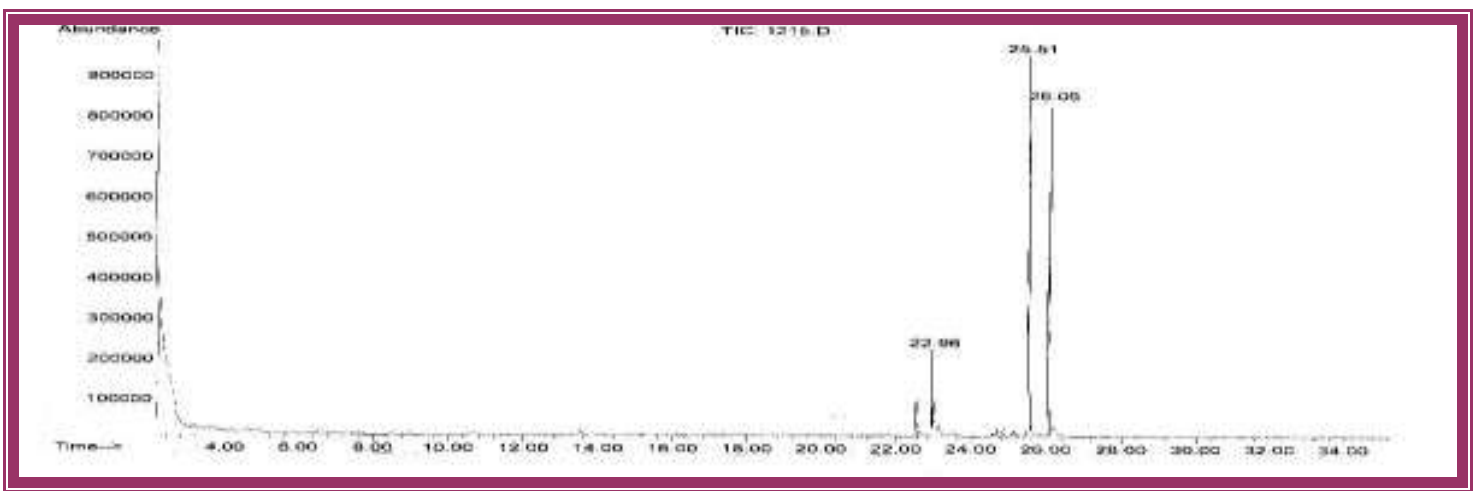

Fig (4): Bromuconazole (Initial) at one hour before and after $3 \& 14$ days of storage at $54{ }^{\circ} \mathrm{C}$

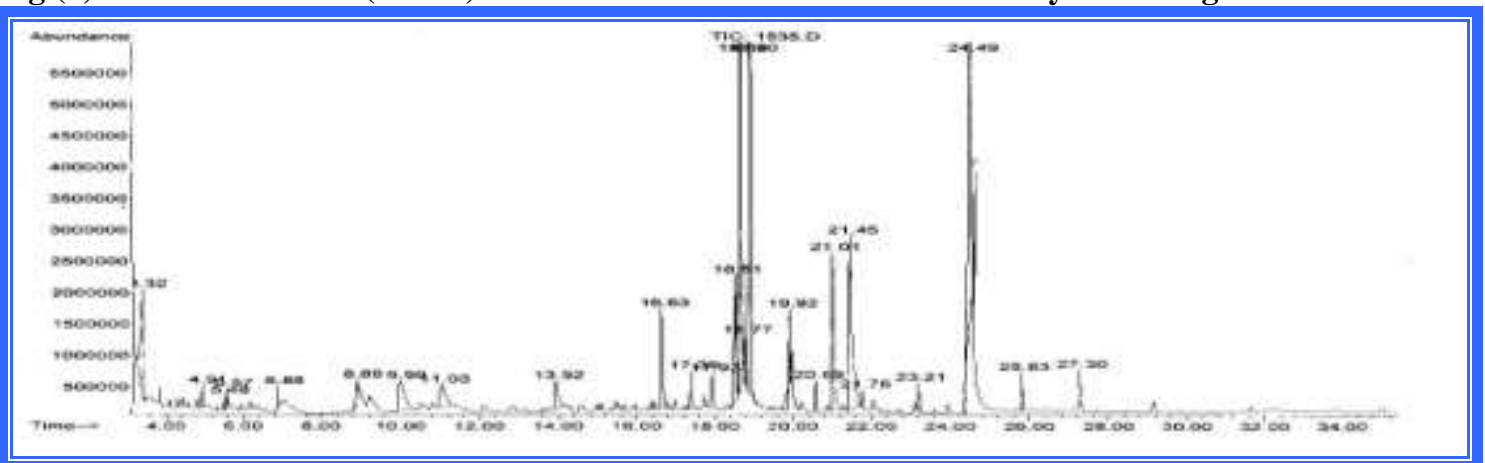

Fig (5):GC/MS chromatogram of Bromuconazole after 3 days of storage at $72^{\circ} \mathrm{C}$ 
Table (5) : Residues of bromuconazole (ppm) on and in unwashed and washed cucumber fruits under field conditions at different time intervals.

\begin{tabular}{|c|c|c|c|c|c|c|c|c|}
\hline \multirow{2}{*}{$\begin{array}{l}\text { Days after } \\
\text { treatment }\end{array}$} & \multicolumn{8}{|c|}{ Bromuconazole } \\
\hline & ${ }_{\text {(1) }}^{\text {ppm }}$ & $\begin{array}{c}\text { unwa } \\
\text { Loss } \\
\text { (2) }\end{array}$ & (1) & $\begin{array}{l}\text { ppm } \\
\text { (2) }\end{array}$ & (1) & $\begin{array}{c}\text { wash } \\
\text { Loss } \\
\text { (2) }\end{array}$ & (1) & (2) \\
\hline Initial & 0.5995 & 0.8627 & $\ldots \ldots$ & & 0.4734 & 0.3622 & 21.03 & 58.02 \\
\hline 1 & 0.2782 & 0.1614 & 53.59 & 81.92 & 0.2103 & ND & 64.92 & 100 \\
\hline 3 & 0.1648 & ND & 72.51 & 100 & 0.1117 & ND & 81.37 & 100 \\
\hline 5 & 0.1547 & ND & 74.19 & 100 & 0.0901 & ND & 84.97 & 100 \\
\hline 7 & 0.1333 & ND & 77.76 & 100 & 0.0064 & ND & 98.93 & 100 \\
\hline 14 & 0.0743 & ND & 87.60 & 100 & 0.0007 & ND & 99.88 & 100 \\
\hline $\mathbf{R I}_{50}$ & \multicolumn{2}{|c|}{ (1)22.39 hour } & \multicolumn{2}{|c|}{ (2)14.65 h. } & \multicolumn{2}{|c|}{ (1)18.48 h. } & \multicolumn{2}{|c|}{ (2)12.00h. } \\
\hline
\end{tabular}

1= Bromuconazole L- $5850646(5 \%) \quad\} \quad 10 \%$ Bromuconazole - 2= Bromuconazole L- 5850647 (5\%)

days . Also, the results showed that the percentages of match were $100,98.68$ and 96.13 $\%$, after storage at $54^{\circ} \mathrm{C}$ for $3 \& 14$ days and at 72 ${ }^{\circ} \mathrm{C}$ for 3 days, respectively (Table , 3) characteristic IR absorbance obtained by(CRC hand book 1994).

\subsubsection{HNMR spectra of bromuconazole}

HNMR spectra of bromuconazole revealed the following signals $\delta$ ppm $2.571(\mathrm{H}$ of $(\mathrm{CH} 2) ; \delta$ ppm at 3.7-3.4 ( $\mathrm{H}$ of $-\mathrm{CH} 2-\mathrm{O}-\mathrm{CH} 2)^{\prime} \delta \mathrm{ppm}$ at 8.09 ( $\mathrm{H}$ of aromatic protons )

( Fig 3).

\subsubsection{Effect of storage temperatures on separation and fragmentation of bromuconazole fungicide formulation by GC/MS}

The results in Table (4) and Fig (4) show that the bromuconazole formulation gave the same separation compound before and after storage at $54^{\circ} \mathrm{C}$ for $3 \& 14$ days storage. The results in Table (4) and Fig.(5) show the different separation compounds with many degradation after storage at $72^{\circ} \mathrm{C}$ for 3 days .

\subsection{Total residues in cucumber fruits}

The data in Table ( 5 ) demonstrate the initial deposits and the residual behavior of bromuconazole on cucumber fruits after treatment. The initial deposits revealed that the amounts of deposits depended on the nature of the treated surface and the relation between the treated surface and its weight (El-Sayed et al.,1976). The results indicated that the initial deposits of bromuconazole residues in washed and unwashed cucumber fruits as determined one hour after application were $0.5995 \& 0.8627 \mathrm{ppm}$ for bromuconazole L- 5850646 \& L- 5850647, respectively. The residue level of initial deposits with bromuconazole is due to many factors, the ratio of surface to mass area and character of treated surface (smooth or rough and waxy or non waxy) (Abo El- Ghar and Ramadan 1962 ; Juan et al., 2007 ;and Mazur et al., 2008) .Moreover, some pesticides are rapidly degraded in open field by sunlight and its stability in some crops which with waxy layer of fruit surface that absorbs or reflects the rays,(Cabras et al., 1990). One day after treatment, the residue were $0.2782 \& 0.1614$ ppm for bromuconazole L- 5850646 \& L5850647 , respectively.

From the previous results, it is of a great interest to note the following remarks. Storage at high temperature conditions had not significant effect on the physical properties of bromuconazole formulations while the active ingredients in bromuconazole were degraded but within the permissible limits for FAO Pesticides Specification (2006) . In conclusion, it is clear that the Vectra (bromuconazole) was more stable and Tolerate to be stored at different temperature conditions.

\section{REFERENCES}

Abo-El- Ghar M.R. and Ramadan M.M. (1962). Studies on residue of certain organophosphorus insecticides on some vegetables. Bull. Soc.Ent. Egypt, pp.359-363.

Barbara. S. (1985). Modern infrared spectroscopy published on behalf of Acol (University of Greenwich) by John Wiley \&Sons Chichester, New Yourk . Brisban. Toranto. Singapore.

Cabras P.,Spaneda L, Cabitza F. , Cubedda M., Martini G.M. and Brandolini V. (1990). Primicarb and its metabolite residues in letter influence of culture environment. H. Agric. Food Chem.; 38:879-882.

CRC hand book (1994).Chemistry and physics 75 ${ }^{\text {th }}$ (ed.) Boca Raton, FL; CRC Press, 9-79.

El- Sayed, M.M., Doghiem S. M. , Hindi S.A , Shahin A. and Abdel-Salam M. (1976). Persistence of certain organophosphorus insecticides on some vegetables. Bull. Ent. Soc. Egypt., Econ. Ser. 10:41-49. 
Emara Ola M. Y.(2006). Residual behavior of fenthion and fenpyroximate on orange fruits . Egypt. J. of Appl. Sci. , 21(613),743-750.

Emara Ola M. Y. and Abd El- Aziz Shereen A. (2007). Effect of storage temperature on the stability of chemical and physical properties of certain local organophosphorus insecticide formulations. Egypt. J.of Appl.Sci.,m22 (2B):813-828.

Emara Ola M. Y. and Attalla I.M.M. (2006). Tetraconazole and indoxacarb pesticides residues in and on tomato fruits and effect of some environmental factors. J.Agric.Sci.Mansoura Univ.,31(8):5417-5424.

FAO/WHO meeting (2002). The tolerance for formulated products Manual on development and use of FAO and WHO specifications for Pesticides. First edition, P31.

Gad S.C. and Weil C .S.(1989). Statistics for toxicologist principles and methods of toxicology. Hayes, AW. (Ed) $2^{\text {nd }}$ ed. Raven Press. Ltd., New York, PP. 435-483.

Gfont M., J. Redondo , Loranzini $\mathrm{R}$ and Valenzuela A.I. (1999). Matrix solid phase dispersion micro extraction and determination by HPLC with UV detection of pesticide residues in Citrus fruits. J. Chromattogr.A. 16; 839 (1-2):101-107.

Hala M.I.(2003). Determination of some pesticide residues in fresh agriculture produce available at local market in Egypt. M.Sc. Thesis , Faculty of Science, Helwan University.

Juan F. García-Reyes M. Dolores Hernando, Carmen Ferrer , Antonio Molina-Díaz, and Amadeo R. Fernández-Alba.(2007). Large Scale Pesticide Multiresidue Methods in Food Combining Liquid Chromatography- Time-ofFlight Mass Spectrometry and Tandem Mass Spectrometry. Anal. Chem., 79 (19), pp 73087323.

Lidia M. R.P., Javier ,H.B. and Maguel A.R D.(2006). Pesticides analysis by LC and capillary electrophoresis. J. Separation Sci. Vol. 29- Issue 17 :2557-2577.

Mazur C. S., J. F. Kenneke C. T. Stevens M. S. Okino and Lipscomb J. C. (2008). In vitro metabolism of the fungicide and environmental contaminant trans-bromuconazole and implications for risk assessment. Taylor \& Francis, Inc., Philadelphia, PA, 70(14):12411250.

Nasr I.N. (2002). Persistence of primiphos-methyl residues on and in pepper and chili fruits and soil. The first Conf. of the Central Agric. Pesticide 106,3-5 Sept., P. 1-7. Central Agric. Pesticide Lab., Agric. Res. Center, Dokki, Giza.

Osman M. A., Radwan O.A. and Nasr M.(2004). Determination of chlorphenapyr and abamectin residues in cucumber fruits. The second conf.on the role of biochemistry in environment and agriculture, part II February 24-27.Pages.450-458.

Pesticide Analytical Manual (2004). Volume I. Food and Drug Administration, Washington, DC. National Technical Information Service, Springfield, VA. USA.

Pesticides specifications,(2006). Prepared by the FAO/WHO Joint meeting on Pesticide Specifications (JMPS),PP:36.

Radwan O.A.(2010). Effect of storage condition on the stability of physicochemical and properties of diazinon insecticide formulation and its residue in Oreochromic niloticus. Egypt, J. Agric. Res.,88(2):495-506.

Radwan O. A. and Attalla I.E. (2009). Effect of storage temperature on the stability of chemical and physical properties with determination of malathion and fenitrothion insecticides formulations residues in cucumber fruits. $J$. Biol. Chem. Environ.Sci., Vol.4(3):813-830.

Saad M.M., Ali H.M. and Ramadan Habiba A. (1993). GC-ECD and GC-MS analysis of profenfos residues and its biochemical effects in tomatoes and tomato products. J.Agric. Food Chem.41:610-615.

Sandro N. , Claudis P .D and Rogerio L. D.(2010). Multiresidue determination of carbamate, organochlorine, organophosphorus and dicarboximide pesticides in Lettuce by GC/MS. J.Environ.Sci. Health B. Aug; 45(6): 589-594.

WHO (1979). Specifications for pesticides used in public health, P.116 Geneva, Switzerland.

WHO (1985). Specifications for pesticides used in public health. ( $6^{\text {th }}$ edition), P.374.Geneva, Switzerland. 


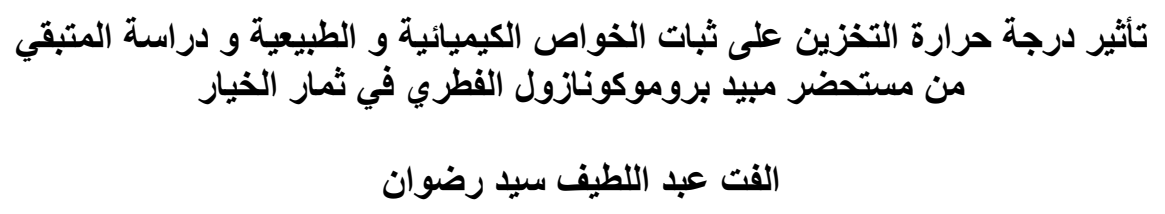

قسم بحوث تحليل المبيدات ـ المعمل المركزي للمبيدات ـ مركز البحوث الزراعية الدقيـ الجيزة - مصر

\section{ملخص}

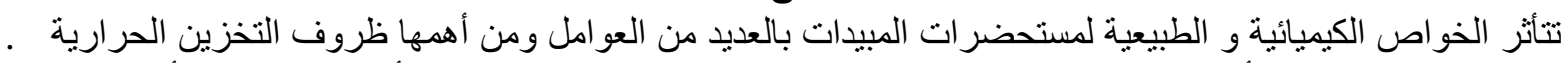

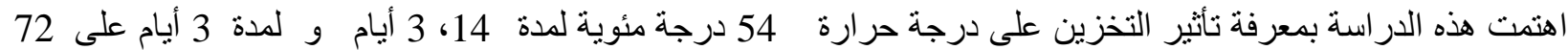

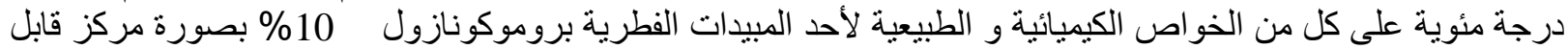

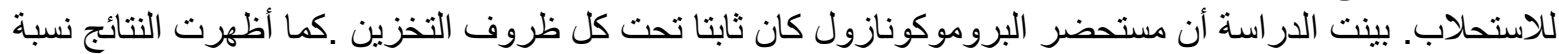

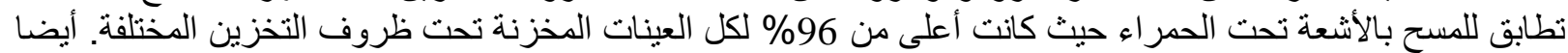

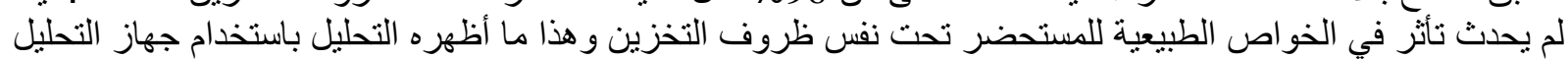

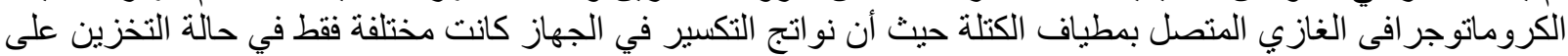

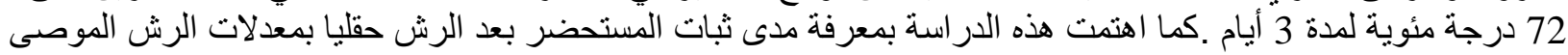

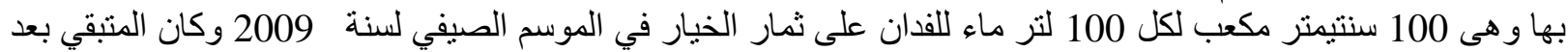

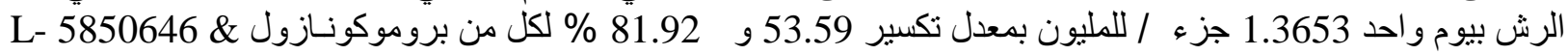
(L- 5850647)

كما أوضحت النتائج أن فترة نصف الحياة على الثمار بعد الحصاد بدون غسيل بلغت 22.39 , 24.65 ساعة كما أدت فئ عملية غسيل الثمار إلى خفض و اضح في في فترة نصف الحياة لمستحضر البروموكونازول حيث وصلت إلى

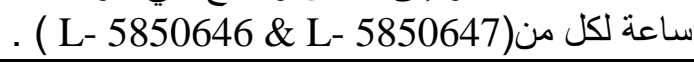

المجلة العلمية لكلية الزراعة - جامعة القاهرة (المجلا262) العدد الثانى (أبريل 2011):242-245. 